\title{
Subsolidus Phase Relations of the SrO-In2O3-CuO System in Air
}

\section{Grivel, Jean-Claude; Thydén, Karl Tor Sune}

Published in:

Journal of Phase Equilibria and Diffusion

Link to article, DOI:

$10.1007 / \mathrm{s} 11669-013-0187-4$

Publication date:

2013

Document Version

Publisher's PDF, also known as Version of record

Link back to DTU Orbit

Citation (APA):

Grivel, J-C., \& Thydén, K. T. S. (2013). Subsolidus Phase Relations of the SrO- $\ln _{2} \mathrm{O}_{2}$-CuO System in Air. Journal of Phase Equilibria and Diffusion, 34(2), 89-93. https://doi.org/10.1007/s14669-013-0187-4

\section{General rights}

Copyright and moral rights for the publications made accessible in the public portal are retained by the authors and/or other copyright owners and it is a condition of accessing publications that users recognise and abide by the legal requirements associated with these rights.

- Users may download and print one copy of any publication from the public portal for the purpose of private study or research.

- You may not further distribute the material or use it for any profit-making activity or commercial gain

- You may freely distribute the URL identifying the publication in the public portal

If you believe that this document breaches copyright please contact us providing details, and we will remove access to the work immediately and investigate your claim 


\title{
Subsolidus Phase Relations of the $\mathrm{SrO}-\mathrm{In}_{2} \mathrm{O}_{3}-\mathrm{CuO}$ System in Air
}

\author{
J.-C. Grivel and K. Thyden
}

\begin{abstract}
(Submitted June 15, 2012; in revised form November 12, 2012; published online January 24, 2013)
The subsolidus phase relations of the $\mathrm{SrO}-\mathrm{In}_{2} \mathrm{O}_{3}-\mathrm{CuO}$ system were investigated at $900{ }^{\circ} \mathrm{C}$ in air. Under these conditions, five binary oxide phases are stable: $\mathrm{Sr}_{2} \mathrm{CuO}_{3}, \mathrm{SrCuO}_{2}, \mathrm{Sr}_{14} \mathrm{Cu}_{24} \mathrm{O}_{41}$, $\mathrm{In}_{2} \mathrm{Cu}_{2} \mathrm{O}_{5}$ and $\mathrm{SrIn}_{2} \mathrm{O}_{4}$. The pseudo-ternary section is characterised by six three-phase regions and is dominated by the $\operatorname{SrIn}_{2} \mathrm{O}_{4}$ phase, which is in equilibrium with all other phases. No Sr equivalents of the $\mathrm{Ca}_{8} \mathrm{In}_{2} \mathrm{Cu}_{4} \mathrm{O}_{15}, \mathrm{Ca}_{9} \mathrm{In}_{14} \mathrm{Cu}_{2} \mathrm{O}_{32}, \mathrm{Ba}_{2} \mathrm{In}_{2} \mathrm{CuO}_{6}, \mathrm{Ba}_{2} \mathrm{InCuO}_{4.5}$ or $\mathrm{Ba}_{3} \mathrm{In}_{4} \mathrm{Cu}_{3} \mathrm{O}_{12}$ phases were formed.
\end{abstract}

Keywords $\mathrm{CuO}, \mathrm{In}_{2} \mathrm{O}_{3}$, phase equilibria, $\mathrm{SrO}$, x-ray diffraction

\section{Introduction}

After the discovery of superconducting compounds with high critical temperature $\left(T_{\mathrm{c}}\right)$ in the Tl-Ba-Ca-Cu-O system, ${ }^{[1]}$ attempts have been made to replace thallium by harmless elements, in particular indium, which is located just above $\mathrm{Tl}$ in the periodic table. However, as reported by Hur et al. ${ }^{[2]}$ the solubility limit of In in the phase having the highest $T_{\mathrm{c}}$ is limited to about 20 at. $\%$ and In actually results in partial suppression of the superconducting properties. In contrast, superconductivity was observed in the In-based cuprates $\mathrm{In}_{0.3} \mathrm{~Pb}_{0.7} \mathrm{Ca}_{0.8} \mathrm{Y}_{0.2} \mathrm{Sr}_{2} \mathrm{Cu}_{2} \mathrm{O}_{y}$ and $(\mathrm{Bi}, \mathrm{In}) \mathrm{Sr}_{2}(\mathrm{Gd}, \mathrm{Ca}) \mathrm{Cu}_{2} \mathrm{O}_{y}$ with $T_{\mathrm{c}}$ values of 60 and $42 \mathrm{~K}$ respectively. ${ }^{[3,4]}$ The effect of In substitution in a variety of superconducting cuprates differs significantly depending on the particular compound. In $\mathrm{Bi}_{2} \mathrm{Sr}_{2} \mathrm{Ca}_{2} \mathrm{Cu}_{3} \mathrm{O}_{10}, \quad \mathrm{HgBa}_{2} \mathrm{CaCu}_{2} \mathrm{O}_{6}$ and (La,Gd)CaBa $\mathrm{Cu}_{7} \mathrm{O}_{z}$, In doping is detrimental to the superconducting properties. ${ }^{[5-7]}$ In contrast, in $\mathrm{YBa}_{2} \mathrm{Cu}_{3} \mathrm{O}_{7}$, a small amount of In substitution for Y appears to increase $T_{\mathrm{c}}$ slightly, ${ }^{[8]}$ whereas it can even induce superconductivity in $(\mathrm{Nd}, \mathrm{Ce})_{2} \mathrm{CuO}_{4-y .}{ }^{[9]}$ Interestingly, superconductivity can be induced by $\mathrm{Zn}$ doping in $\mathrm{In}_{2} \mathrm{O}_{3}{ }^{[10]}$ The synthesis of a layered cuprate with composition reminiscent to that of some superconducting cuprates, i.e. $\operatorname{In}_{2} \mathrm{Ba}_{2} \mathrm{CuO}_{6-\delta}$, was also reported ${ }^{[11]}$ but this compound appears to be an insulator.

Whereas the phase equilibria of the pseudo-ternary systems $\mathrm{CaO}-\mathrm{In}_{2} \mathrm{O}_{3}-\mathrm{CuO}$ and $\mathrm{BaO}-\mathrm{In}_{2} \mathrm{O}_{3}-\mathrm{CuO}$ have been published, ${ }^{[12,13]}$ we are not aware of reports on the $\mathrm{SrO}$ $\mathrm{In}_{2} \mathrm{O}_{3}-\mathrm{CuO}$ system. We have therefore determined the phase equilibria in the latter system in view of the possible occurrence of new ternary oxide phases as well as in order to provide a comparison with related systems.

J.-C. Grivel and K. Thyden, Department of Energy Conversion and Storage, Technical University of Denmark, Frederiksborgvej 399, 4000 Roskilde, Denmark. Contact e-mail: jean@dtu.dk

\subsection{Previous Work}

Under ambient pressure conditions, $\operatorname{In}_{2} \mathrm{O}_{3}$ crystallises in the Ia-3 space group (cubic). ${ }^{[14]}$ Several studies ${ }^{[15-20]}$ have been devoted to the $\mathrm{SrO}-\mathrm{CuO}$ system, in which three phases are known to be stable at $800{ }^{\circ} \mathrm{C}$ in air: $\mathrm{Sr}_{2} \mathrm{CuO}_{3}$ (orthorhombic, space group $\mathrm{Immm}^{[21]}$ ), $\mathrm{SrCuO}_{2}$ (orthorhombic, space group $\mathrm{Cmcm}^{[21]}$ ) and $\mathrm{Sr}_{14} \mathrm{Cu}_{24} \mathrm{O}_{41}$, which is sometimes described as $\mathrm{Sr}_{3} \mathrm{Cu}_{5} \mathrm{O}_{8}$ (orthorhombic, space group $\mathrm{Fmmm}^{[22]}$ ). Under conditions of lower oxygen partial pressure, an additional binary oxide with $\mathrm{SrCu}_{2} \mathrm{O}_{2}$ composition was observed. ${ }^{[20,23]}$ The $\mathrm{SrCu}_{2} \mathrm{O}_{3}$ and $\mathrm{Sr}_{2} \mathrm{Cu}_{3} \mathrm{O}_{5}$ phases were synthesised under high pressure (1.7-8 GPa). ${ }^{[24]}$

According to the $\mathrm{BaO}-\mathrm{In}_{2} \mathrm{O}_{3}-\mathrm{CuO}$ and $\mathrm{CaO}-\mathrm{In}_{2} \mathrm{O}_{3}-\mathrm{CuO}$ phase equilibrium studies published by Horyń et al. ${ }^{[12]}$ and Godzhieva et al. ${ }^{[13]}$ respectively, in air in the temperature range $900-950{ }^{\circ} \mathrm{C}$, the $\mathrm{In}_{2} \mathrm{O}_{3}-\mathrm{CuO}$ pseudo binary system contains only one binary oxide phase: $\mathrm{In}_{2} \mathrm{Cu}_{2} \mathrm{O}_{5}$. The structure of this compound has been refined by Freund and Müller-Buschbaum ${ }^{[25]}$ as orthorhombic (space group $\left.P 2{ }_{1} n b\right) . \mathrm{In}_{2} \mathrm{CuO}_{4}$ single crystals with tetragonal symmetry were grown from a melt consisting of a $0.9 \mathrm{BaO}: 0.1$ $\mathrm{KO}_{0.5}: 2 \mathrm{SrO}: 4 \mathrm{CuO}$ nominal composition by cooling from 1150 to $300{ }^{\circ} \mathrm{C} .{ }^{[26]}$ This phase does not appear in the above mentioned equilibrium diagrams. ${ }^{[12,13]}$

Partial data on the $\mathrm{SrO}-\mathrm{In}_{2} \mathrm{O}_{3}$ system can be found in the $\mathrm{In}_{2} \mathrm{O}_{3}-\mathrm{TiO}_{2}-\mathrm{SrO}$ phase diagram section established by $\mathrm{Li}$ et al. ${ }^{[27]}$ at $1350{ }^{\circ} \mathrm{C}$ in air. Under these conditions, a single binary oxide compound is formed: $\operatorname{SrIn}_{2} \mathrm{O}_{4}$. The structure of this phase (orthorhombic, space group Pnam) was reported by von Schenk and Müller-Buschbaum. ${ }^{[28]} \mathrm{Sr}_{2} \mathrm{In}_{2} \mathrm{O}_{5}$ is only stable at higher temperatures. ${ }^{[29]}$

In the $\mathrm{SrO}-\mathrm{In}_{2} \mathrm{O}_{3}-\mathrm{CuO}$ system, no ternary oxide phase has been reported so far.

\section{Experimental Details}

High purity $\mathrm{In}_{2} \mathrm{O}_{3}, \mathrm{SrCO}_{3}$ and $\mathrm{CuO}$ powders (all $\geq 99.9 \%$ ) were thoroughly mixed in an agate mortar and calcined at $900{ }^{\circ} \mathrm{C}$ for $60 \mathrm{~h}$. In total, 36 nominal compositions were 
Table 1 Phases observed in selected samples after equilibration and crystallographic data for the majority phases

\begin{tabular}{|c|c|c|c|c|c|c|}
\hline \multirow{2}{*}{$\begin{array}{l}\text { Nominal cation ratio } \\
\text { In:Sr:Cu }\end{array}$} & \multirow[b]{2}{*}{ Phases (XRD) ${ }^{\mathbf{a}}$} & \multirow[b]{2}{*}{ Space group ${ }^{b}$} & \multicolumn{4}{|c|}{ Lattice parameters ${ }^{\mathrm{c}}$} \\
\hline & & & $a, \AA$ & $b, \AA$ & $c, \AA$ & $\beta,^{\circ}$ \\
\hline 0:0:100 & $\mathrm{CuO}$ & $C 2 / c$ & $4.692(10)$ & $3.425(2)$ & $5.124(13)$ & $99.52(3)$ \\
\hline $1: 0: 99$ & $\mathrm{CuO}\left(\mathrm{In}_{2} \mathrm{Cu}_{2} \mathrm{O}_{5}\right)$ & $C 2 / c$ & $4.694(11)$ & $3.422(2)$ & $5.124(15)$ & $99.54(4)$ \\
\hline $49: 0: 51$ & $\mathrm{In}_{2} \mathrm{Cu}_{2} \mathrm{O}_{5}(\mathrm{CuO})$ & $P 2_{1} n b$ & $12.291(5)$ & $10.538(4)$ & $3.279(2)$ & $\ldots$ \\
\hline $50: 0: 50$ & $\mathrm{In}_{2} \mathrm{Cu}_{2} \mathrm{O}_{5}$ & $P 2_{1} n b$ & $12.298(4)$ & $10.547(3)$ & $3.281(1)$ & $\ldots$ \\
\hline $51: 0: 49$ & $\mathrm{In}_{2} \mathrm{Cu}_{2} \mathrm{O}_{5}\left(\mathrm{In}_{2} \mathrm{O}_{3}\right)$ & $P 2_{1} n b$ & $12.296(3)$ & $10.538(3)$ & $3.279(1)$ & $\ldots$ \\
\hline $50: 1: 49$ & $\mathrm{In}_{2} \mathrm{Cu}_{2} \mathrm{O}_{5}\left(\mathrm{In}_{2} \mathrm{O}_{3}, \mathrm{SrIn}_{2} \mathrm{O}_{4}\right)$ & $P 2_{1} n b$ & $12.307(7)$ & $10.549(5)$ & $3.280(2)$ & $\ldots$ \\
\hline $49: 1: 50$ & $\mathrm{In}_{2} \mathrm{Cu}_{2} \mathrm{O}_{5}\left(\mathrm{CuO}, \mathrm{SrIn}_{2} \mathrm{O}_{4}\right)$ & $P 2_{1} n b$ & $12.306(7)$ & $10.552(5)$ & $3.282(2)$ & $\ldots$ \\
\hline $99: 1: 0$ & $\mathrm{In}_{2} \mathrm{O}_{3}\left(\mathrm{SrIn}_{2} \mathrm{O}_{4}\right)$ & Ia-3 & $10.117(4)$ & $\ldots$ & $\ldots$ & $\ldots$ \\
\hline 100:0:0 & $\mathrm{In}_{2} \mathrm{O}_{3}$ & $I a-3$ & $10.118(3)$ & $\ldots$ & $\ldots$ & $\ldots$ \\
\hline $99: 0: 1$ & $\mathrm{In}_{2} \mathrm{O}_{3}\left(\mathrm{In}_{2} \mathrm{Cu}_{2} \mathrm{O}_{5}\right)^{\mathrm{d}}$ & $I a-3$ & $10.114(3)$ & $\ldots$ & $\ldots$ & $\ldots$ \\
\hline $98: 0: 2$ & $\mathrm{In}_{2} \mathrm{O}_{3}\left(\mathrm{In}_{2} \mathrm{Cu}_{2} \mathrm{O}_{5}\right)$ & $I a-3$ & $10.121(3)$ & $\ldots$ & $\ldots$ & $\ldots$ \\
\hline $68: 32: 0$ & $\mathrm{SrIn}_{2} \mathrm{O}_{4}\left(\operatorname{In}_{2} \mathrm{O}_{3}\right)$ & Pnam & $9.842(5)$ & $11.494(4)$ & $3.261(3)$ & $\ldots$ \\
\hline $2 / 3: 1 / 3: 0$ & $\mathrm{SrIn}_{2} \mathrm{O}_{4}$ & Pnam & $9.833(3)$ & $11.491(2)$ & $3.265(1)$ & $\ldots$ \\
\hline $66: 34: 0$ & $\mathrm{SrIn}_{2} \mathrm{O}_{4}(\mathrm{SrO})$ & Pnam & $9.839(4)$ & $11.490(4)$ & $3.264(2)$ & $\ldots$ \\
\hline $65.67: 33.33: 1$ & $\mathrm{SrIn}_{2} \mathrm{O}_{4}\left(\mathrm{Sr}_{14} \mathrm{Cu}_{24} \mathrm{O}_{41}\right)$ & Pnam & $9.834(4)$ & $11.499(3)$ & $3.264(2)$ & $\ldots$ \\
\hline $66.67: 32.33: 1$ & $\mathrm{SrIn}_{2} \mathrm{O}_{4}\left(\mathrm{In}_{2} \mathrm{O}_{3}, \mathrm{In}_{2} \mathrm{Cu}_{2} \mathrm{O}_{5}\right)$ & Pnam & $9.832(5)$ & $11.494(5)$ & $3.263(3)$ & $\cdots$ \\
\hline $1.00: 66.67: 32.33$ & $\mathrm{Sr}_{2} \mathrm{CuO}_{3}\left(\mathrm{SrIn}_{2} \mathrm{O}_{4}, \mathrm{SrO}\right)$ & Immm & $12.701(1)$ & $3.912(1)$ & $3.499(1)$ & $\cdots$ \\
\hline $0.00: 66.67: 33.33$ & $\mathrm{Sr}_{2} \mathrm{CuO}_{3}$ & Immm & $12.704(1)$ & $3.913(1)$ & $3.500(1)$ & $\ldots$ \\
\hline $1.00: 65.67: 33.33$ & $\mathrm{Sr}_{2} \mathrm{CuO}_{3}\left(\mathrm{SrIn}_{2} \mathrm{O}_{4}, \mathrm{SrCuO}_{2}\right)$ & Immm & $12.701(1)$ & $3.912(1)$ & $3.499(1)$ & $\ldots$ \\
\hline $1: 50: 49$ & $\mathrm{SrCuO}_{2}\left(\mathrm{SrIn}_{2} \mathrm{O}_{4}, \mathrm{Sr}_{2} \mathrm{CuO}_{3}\right)$ & $\mathrm{Cmcm}$ & $3.572(1)$ & $16.328(3)$ & $3.913(2)$ & $\ldots$ \\
\hline $0: 50: 50$ & $\mathrm{SrCuO}_{2}$ & $\mathrm{Cmcm}$ & $3.572(1)$ & $16.325(2)$ & $3.914(2)$ & $\ldots$ \\
\hline $1: 49: 50$ & $\mathrm{SrCuO}_{2}\left(\mathrm{SrIn}_{2} \mathrm{O}_{4}, \mathrm{Sr}_{14} \mathrm{Cu}_{24} \mathrm{O}_{41}\right)$ & Cmcm & $3.571(1)$ & $16.322(2)$ & $3.912(2)$ & $\ldots$ \\
\hline $0.5: 14.0: 23.5$ & $\mathrm{Sr}_{14} \mathrm{Cu}_{24} \mathrm{O}_{41}\left(\mathrm{SrIn}_{2} \mathrm{O}_{4}, \mathrm{SrCuO}_{2}\right)$ & Cccm & $11.464(3)$ & $13.400(1)$ & $27.64(1)$ & $\ldots$ \\
\hline $0.0: 14.0: 24.0$ & $\mathrm{Sr}_{14} \mathrm{Cu}_{24} \mathrm{O}_{41}$ & $\mathrm{Cccm}$ & $11.465(8)$ & $13.401(3)$ & $27.64(2)$ & $\ldots$ \\
\hline $0.5: 13.5: 24.0$ & $\mathrm{Sr}_{14} \mathrm{Cu}_{24} \mathrm{O}_{41}\left(\mathrm{CuO}, \mathrm{SrIn}_{2} \mathrm{O}_{4}\right)$ & Cccm & $11.473(6)$ & $13.405(3)$ & $27.62(2)$ & $\cdots$ \\
\hline \multicolumn{7}{|c|}{${ }^{a}$ Phases between brackets are minority phases } \\
\hline \multicolumn{7}{|c|}{${ }^{\mathrm{b}}$ Space group of the majority phase } \\
\hline \multicolumn{7}{|c|}{${ }^{\mathrm{c}}$ The lattice parameters are those of the majority phase } \\
\hline${ }^{\mathrm{d}}$ Detected by SEM/ED & not by XRD & & & & & \\
\hline
\end{tabular}

studied. After grinding, pellets were pressed under a pressure of $1.8 \mathrm{kbar}$ and sintered at $900{ }^{\circ} \mathrm{C}$ for $60 \mathrm{~h}$. Additional heat treatments under similar conditions with intermediate grinding and pressing were performed until equilibrium was reached. The samples were air-quenched at the end of the sintering treatments. All heat treatments were performed in air.

The phase content of the pellets was checked after each heat treatment by x-ray diffraction (XRD) in a STOE diffractometer using $\mathrm{Cu}-\mathrm{K}_{\alpha}$ radiation. Equilibrium was considered as achieved if no differences were detectable in the XRD patterns collected after two consecutive sintering treatments. Silicon powder was added as an internal standard for lattice parameter determinations in selected samples using the UnitCell leastsquares refinement programme. ${ }^{[30]}$ Scanning electron microscopy (SEM) and local compositional analysis were performed in a TM3000 Tabletop Microscope from HITACHI equipped with a QUANTAX 70 EDS analysis system.

\section{Results and Discussion}

\subsection{SrO-CuO}

Three binary oxide phases were formed at $900{ }^{\circ} \mathrm{C}$ in air: $\mathrm{Sr}_{2} \mathrm{CuO}_{3}, \mathrm{SrCuO}_{2}$ and $\mathrm{Sr}_{14} \mathrm{Cu}_{24} \mathrm{O}_{41}$, in agreement with previous reports. ${ }^{[15-20]}$ The $\mathrm{SrCu}_{2} \mathrm{O}_{2}$ phase was not found in the present study as a consequence of the lack of stability of this phase in air. ${ }^{[20,23]}$ The high-pressure phases $\mathrm{SrCu}_{2} \mathrm{O}_{3}$ and $\mathrm{Sr}_{2} \mathrm{Cu}_{3} \mathrm{O}_{5}{ }^{[24]}$ were not formed either.

\section{$3.2 \ln _{2} \mathrm{O}_{3}-\mathrm{CuO}$}

In agreement with the results presented in Ref 12 and 13, $\mathrm{In}_{2} \mathrm{Cu}_{2} \mathrm{O}_{5}$ is the only binary oxide phase stable at $900{ }^{\circ} \mathrm{C}$ in air in this system. The detection of $\operatorname{In}_{2} \mathrm{Cu}_{2} \mathrm{O}_{5}$ in the sample with $\mathrm{Cu}_{0.99} \mathrm{In}_{0.01}$ nominal cation composition, coupled with the similar lattice parameters for $\mathrm{CuO}$ in this sample and in 


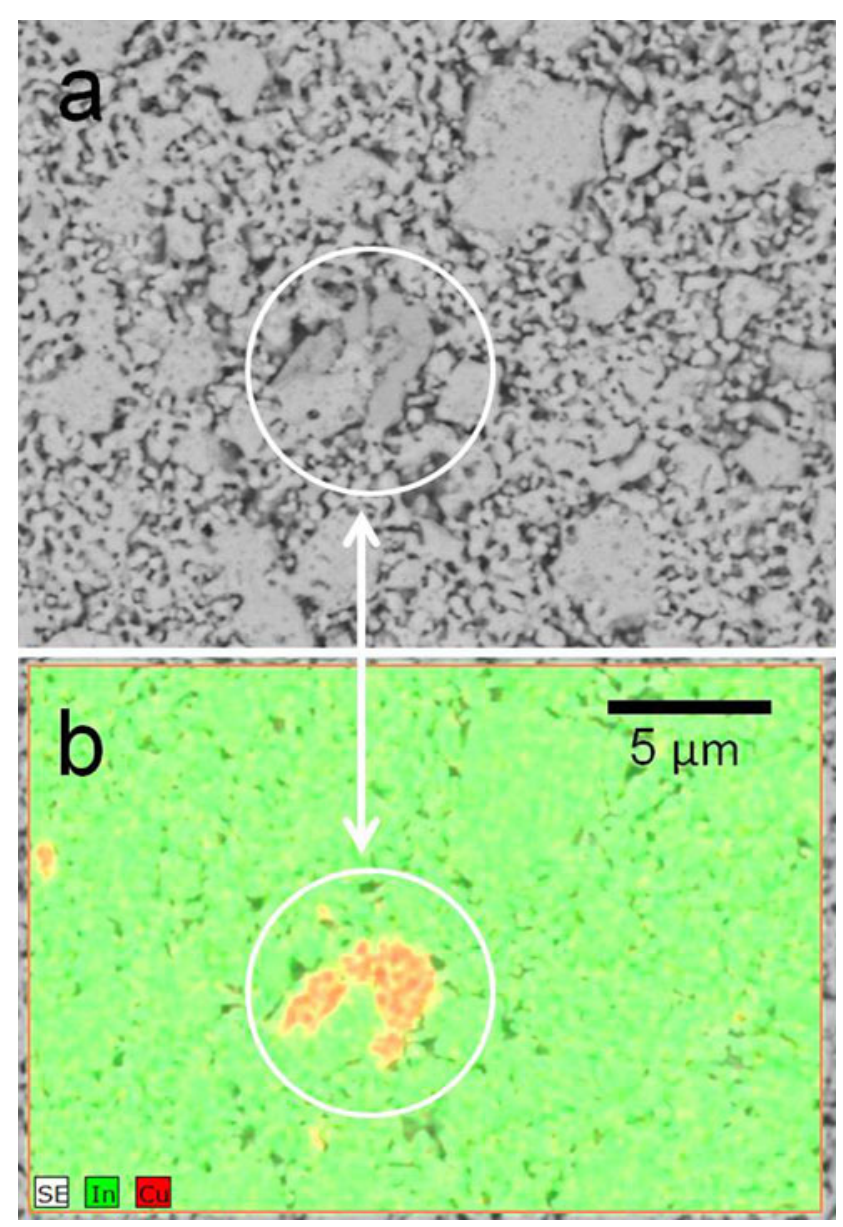

Fig. 1 SEM pictures [(a) backscattering mode and (b) EDS elemental map] showing evidence for coexistence of $\operatorname{In}_{2} \mathrm{Cu}_{2} \mathrm{O}_{5}$ and $\mathrm{In}_{2} \mathrm{O}_{3}$ in the sample with $\mathrm{In}_{0.99} \mathrm{Cu}_{0.01} \mathrm{O}_{y}$ nominal composition. The black areas are due to porosity. The encircled particle has an $\mathrm{In}: \mathrm{Cu}$ atomic ratio of $53 \pm 3: 47 \pm 3$

the pure $\mathrm{CuO}$ sample (Table 1) allow concluding that no extended substitution of In occurs in $\mathrm{CuO}$ under the present experimental conditions. The situation of the $\mathrm{In}_{2} \mathrm{O}_{3}$ rich part of the system is more intricate. In the works of Horyn et al. ${ }^{[12]}$ and Godzhieva et al., ${ }^{[13]}$ no solid state solubility of $\mathrm{Cu}$ in $\mathrm{In}_{2} \mathrm{O}_{3}$ was reported. However, according to a recent report by $\mathrm{Li}$ et al., ${ }^{[31]} 1$ at. $\% \mathrm{Cu}$ can be introduced in $\mathrm{In}_{2} \mathrm{O}_{3}$. Using $\mathrm{InCl}_{3}$ and $\mathrm{CuCl}_{2}$ presursors and annealing at $900{ }^{\circ} \mathrm{C}$ in pure $\mathrm{O}_{2}$, Sasaki et al. ${ }^{[32]}$ even claim that single phase samples are obtained for a nominal composition described as $\mathrm{In}_{2} \mathrm{O}_{3}: \mathrm{Cu}$. In the present study, $\mathrm{In}_{2} \mathrm{Cu}_{2} \mathrm{O}_{5}$ impurities are detected by XRD only in samples with $x \geq 0.02$ in $\mathrm{In}_{1-x} \mathrm{Cu}_{x} \mathrm{O}_{y}$ nominal compositions, whereas the sample with overall stoichiometry corresponding to a $\mathrm{In}: \mathrm{Cu}=99: 1$ atomic ratio appears to be single phase. However, the lattice parameter of the $\mathrm{In}_{2} \mathrm{O}_{3}$ phase is not affected within the accuracy limit of our measurements. Due to the limited resolution of $\mathrm{x}$-ray diffraction, microscopical observations were performed on the " $\mathrm{In}_{0.99} \mathrm{Cu}_{0.01} \mathrm{O}_{y}$ " sample. As shown in Fig. 1, particles characterised by a slightly darker contrast in backscattering mode are present in the sample. EDS

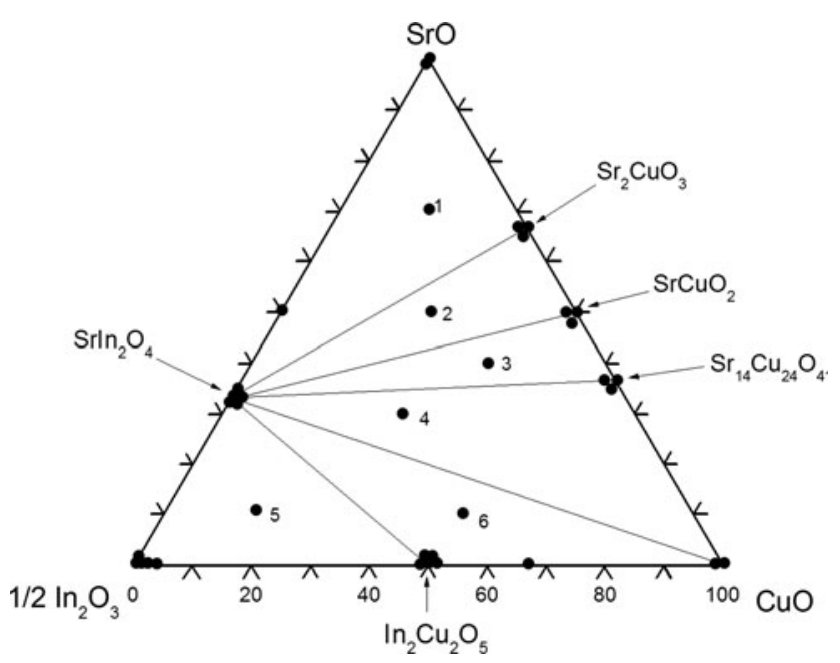

Fig. 2 Phase equilibria of the $\mathrm{SrO}-\mathrm{In}_{2} \mathrm{O}_{3}-\mathrm{CuO}$ system at $900{ }^{\circ} \mathrm{C}$ in air. Dots represent the studied compositions. The numbers 1-6 refer to the XRD patterns that are shown in Fig. 3

analysis on particles with sizes larger than $1 \mu \mathrm{m}$ consistently yield an $\mathrm{In}: \mathrm{Cu}$ atomic ratio close to that corresponding to $\mathrm{In}_{2} \mathrm{Cu}_{2} \mathrm{O}_{5} \quad(\mathrm{In}: \mathrm{Cu}=53 \pm 3: 47 \pm 3)$. These particles are dispersed in an $\mathrm{In}_{2} \mathrm{O}_{3}$ matrix. We therefore conclude that $\mathrm{Cu}$ substitution in $\mathrm{In}_{2} \mathrm{O}_{3}$ must be limited to a value significantly lower than 1 at.\% under the present experimental conditions, in agreement with the data published in Ref 12 and 13. As for the $\mathrm{In}_{2} \mathrm{Cu}_{2} \mathrm{O}_{5}$ phase, it appears to be stoichiometric as deviations from the ideal composition result in equilibrium with either $\mathrm{In}_{2} \mathrm{O}_{3}$ (In excess) or $\mathrm{CuO}$ $(\mathrm{Cu}$ excess) as detailed in Table 1.

\section{$3.3 \mathrm{In}_{2} \mathrm{O}_{3}-\mathrm{SrO}$}

In this pseudo-binary system, $\operatorname{SrIn}_{2} \mathrm{O}_{4}$ is the only binary oxide phase stable under the present conditions.

Due to the strong tendency of $\mathrm{SrO}$ to form $\mathrm{Sr}(\mathrm{OH})_{2} \cdot \mathrm{H}_{2} \mathrm{O}$ upon contact with air, we could not perform accurate lattice parameter determinations in the SrO-rich part of the diagram. However, the clear presence of $\operatorname{SrIn}_{2} \mathrm{O}_{4}$ as inferred by XRD analysis in the sample with $\mathrm{Sr}_{0.99} \mathrm{In}_{0.01} \mathrm{O}_{x}$ nominal composition, suggests that the solubility of $\mathrm{In}$ in $\mathrm{SrO}$ is rather low as previously published, ${ }^{[27]}$ however at a significantly higher temperature $\left(1350{ }^{\circ} \mathrm{C}\right)$. There is no evidence for Sr substitution in $\mathrm{In}_{2} \mathrm{O}_{3}$, as $\mathrm{SrIn}_{2} \mathrm{O}_{4}$ is detected in a sample with $\operatorname{In}_{0.99} \mathrm{Sr}_{0.01} \mathrm{O}_{y}$ nominal composition and the lattice parameters of $\operatorname{In}_{2} \mathrm{O}_{3}$ are not affected by the presence of $\mathrm{Sr}$ (Table 1). Likewise, the $\mathrm{SrIn}_{2} \mathrm{O}_{4}$ phase appears to be stoichiometric.

\section{4 $\mathrm{SrO}-\mathrm{In}_{2} \mathrm{O}_{3}-\mathrm{CuO}$}

The subsolidus tie-line compatibilities of phases in the pseudo-ternary $\mathrm{SrO}-\mathrm{In}_{2} \mathrm{O}_{3}-\mathrm{CuO}$ phase diagram in air at $900{ }^{\circ} \mathrm{C}$ are shown in Fig. 2. There are five binary oxide phases: $\mathrm{Sr}_{2} \mathrm{CuO}_{3}, \mathrm{SrCuO}_{2}, \mathrm{Sr}_{14} \mathrm{Cu}_{24} \mathrm{O}_{41}, \mathrm{In}_{2} \mathrm{Cu}_{2} \mathrm{O}_{5}$ and $\mathrm{SrIn}_{2} \mathrm{O}_{4}$ but no ternary oxide phases. All of the six threephase regions are in contact with the $\mathrm{SrIn}_{2} \mathrm{O}_{4}$ phase, which can thus be in equilibrium with any of the other compounds 


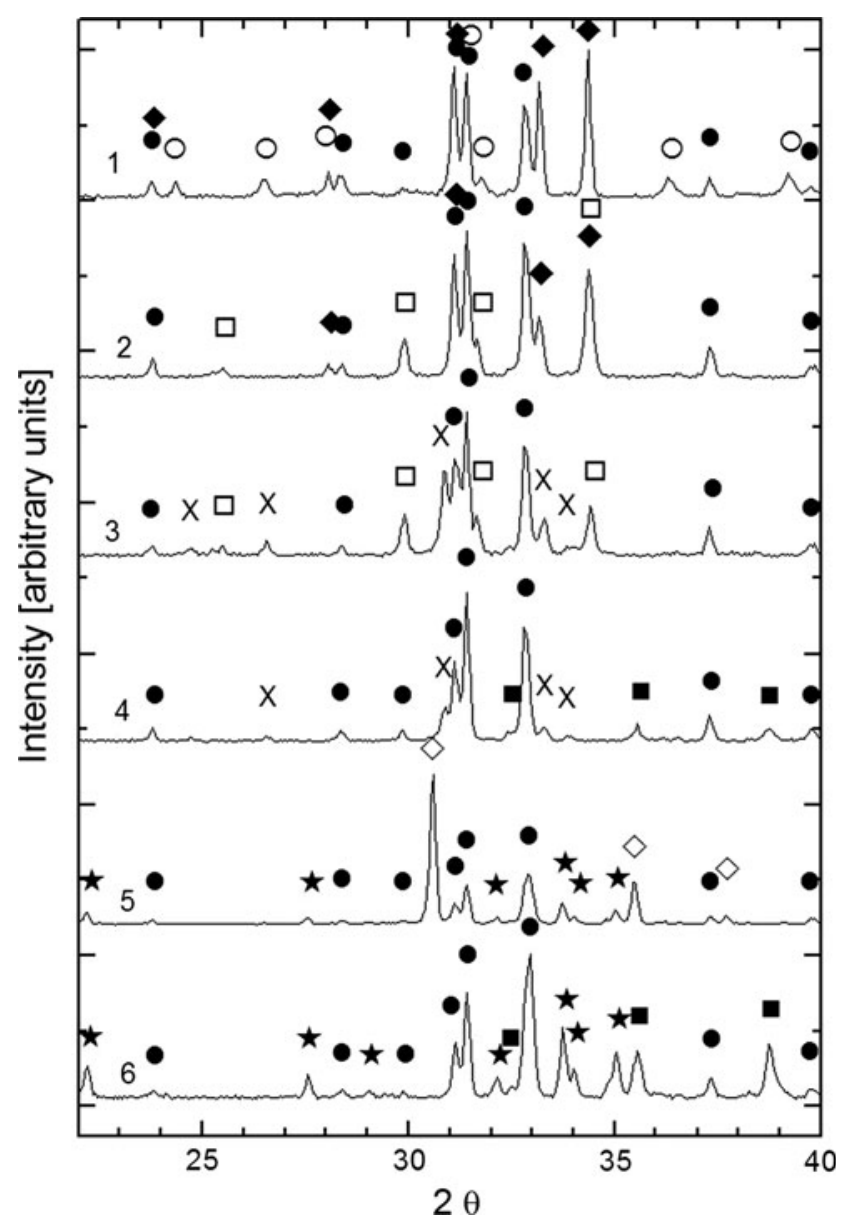

Fig. 3 Representative XRD patterns collected on samples with compositions lying in each of the three-phase regions of the pseudo-ternary sections. The pattern numbers refer to Fig. 2. Phases: $\operatorname{SrIn}_{2} \mathrm{O}_{4}, \bigcirc \mathrm{Sr}(\mathrm{OH})_{2} \cdot \mathrm{H}_{2} \mathrm{O}, \mathrm{Sr}_{2} \mathrm{CuO}_{3}, \square \mathrm{SrCuO}_{2}$, $\mathrm{X} \mathrm{Sr}_{14} \mathrm{Cu}_{24} \mathrm{O}_{41}, \mathbf{C u O}, \diamond \mathrm{In}_{2} \mathrm{O}_{3}$ and $* \mathrm{In}_{2} \mathrm{Cu}_{2} \mathrm{O}_{5}$

depending on the overall composition. Representative XRD patterns for nominal compositions situated in all three-phase regions are shown in Fig. 3. None of the binary oxide phases of the pseudo-binary systems appear to give rise to ternary solid solutions as can be deduced from the appearance of 2-phase or 3-phase equilibria when attempts were made to dope these compounds with the element of the opposite corner (Table 1). The structure of this ternary section is similar to that of the $\mathrm{SrO}-\mathrm{RE}_{2} \mathrm{O}_{3}-\mathrm{CuO}$ systems where $\mathrm{RE}=\mathrm{Sc}, \mathrm{Y}, \mathrm{Lu}, \mathrm{Yb}$, $\mathrm{Tm}$ and $\mathrm{Er}^{[33-37]}$ A general trend of the $\mathrm{SrO}-\mathrm{Ln}_{2} \mathrm{O}_{3}-\mathrm{CuO}$ $(\mathrm{Ln}=$ lanthanide $)$ is that the solubility of the lanthanide element in the $\mathrm{Sr}_{14} \mathrm{Cu}_{24} \mathrm{O}_{41}$ phase decreases as the $\mathrm{Ln}^{3+}$ ion radius decreases. ${ }^{[38]}$ The radius of the $\mathrm{In}^{3+}$ ion is smaller than that of $\mathrm{Lu}^{3+} \cdot{ }^{[39]}$ It is therefore not surprising that no In solid solubility is observed in $\mathrm{Sr}_{14} \mathrm{Cu}_{24} \mathrm{O}_{41}$.

\section{Conclusion}

In air, at $900{ }^{\circ} \mathrm{C}$, the $\mathrm{SrO}-\mathrm{In}_{2} \mathrm{O}_{3}-\mathrm{CuO}$ system contains six three-phase regions and five binary oxide phases $\left(\mathrm{Sr}_{2} \mathrm{CuO}_{3}\right.$,
$\mathrm{SrCuO}_{2}, \mathrm{Sr}_{14} \mathrm{Cu}_{24} \mathrm{O}_{41}, \mathrm{In}_{2} \mathrm{Cu}_{2} \mathrm{O}_{5}$ and $\mathrm{SrIn}_{2} \mathrm{O}_{4}$ ). No ternary oxide phases were formed under the present equilibration conditions. The structure of this ternary section is similar to that of the $\mathrm{SrO}-\mathrm{RE}_{2} \mathrm{O}_{3}-\mathrm{CuO}$ systems where $\mathrm{RE}=\mathrm{Sc}, \mathrm{Y}, \mathrm{Lu}$, $\mathrm{Yb}, \mathrm{Tm}$ and $\mathrm{Er}$, but without $\mathrm{Sr}_{14} \mathrm{Cu}_{24} \mathrm{O}_{41}$-based solid solution.

\section{Acknowledgments}

This work was financed by the Danish Ministry of Science, Technology and Innovation.

\section{References}

1. Z.Z. Sheng and A.M. Hermann, Bulk Superconductivity at $120 \mathrm{~K}$ in the Tl-Ca/Ba-Cu-O System, Nature, 1988, 332, p 138-139

2. N.H. Hur, M. Paranthaman, J.R. Thompson, and D.K. Christen, Superconductivity in the Indium-Doped Tl-1223 Phase: $\left(\mathrm{Tl}_{0.8} \mathrm{In}_{0.2}\right)\left(\mathrm{Sr}_{0.8} \mathrm{Ba}_{0.2}\right)_{2} \mathrm{Ca}_{2} \mathrm{Cu}_{3} \mathrm{O}_{9-\delta}$, Physica C, 1996, 268, p 266-270

3. R.S. Liu, P.T. Wu, S.F. Wu, W.N. Wang, and P.P. Edwards, First Example of Indium as a Practical Alternative to Thallium in High- $T_{\mathrm{c}}$ Superconductors, Physica $C$, 1990, 165, p 111-114

4. G. Cao, Y. Qian, W. Yu, S. Wang, Z. Chen, Y. Huang, and Y. Zhang, Synthesis and Characterization of New Cuprates with a (Bi,In)O Monolayer: (Bi,In) $\mathrm{Sr}_{2}(\mathrm{Gd}, \mathrm{Ca}) \mathrm{Cu}_{2} \mathrm{O}_{y}$, Physica $C$, 1994, 221, p 278-282

5. C.V. Tomy, R. Prasad, N.C. Soni, K. Adhikary, A. Gulnar, and S.K. Malik, Effect of $\mathrm{Sb}, \mathrm{Sn}$ and In Doping on the Superconductivity in Bi-Pb-Sr-Ca-Cu-O System, Solid State Commun., 1990, 74, p 493-496

6. J.Q. Li, C.C. Lam, J. Feng, and K.C. Hung, Effects of In doping in $\mathrm{Hg}_{1-x} \mathrm{In}_{x} \mathrm{Ba}_{2} \mathrm{CaCu}_{2} \mathrm{O}_{6+\delta}$, Supercond. Sci. Technol., 1998, 11, p 217-222

7. R. Vij, D.C. Kundaliya, A.G. Joshi, D.G. Kuberkar, and R.G. Kulkarni, Suppression of Superconductivity in the $\left(\mathrm{La}_{2.5-x} \mathrm{Gd}_{0.5+x}\right) \mathrm{CaBa}_{3-x} \mathrm{Sr}_{x}\left(\mathrm{Cu}_{1-y} \mathrm{In}_{y}\right)_{7} \mathrm{O}_{z}$ System due to Hole Filling by In and Its Revival by Hole Doping with $\mathrm{Ca}$, Physica C, 2002, 371, p 315-320

8. A.K. Bhattacharya and K.K. Singh, High-Temperature Superconducting Properties in the $\mathrm{Y}_{1-x} \mathrm{~A}_{x} \mathrm{Ba}_{2} \mathrm{Cu}_{3} \mathrm{O}_{7-\delta}$ System $(\mathrm{A}=\mathrm{In}, \mathrm{Tl})$, Physica $C, 1988,152, \mathrm{p} 283-285$

9. N.Y. Ayoub, C.C. Almasan, E.A. Early, J.T. Markert, C.L. Seaman, and M.B. Maple, The Effect of Indium Substitution for Copper on the Superconductivity of the Electron-Doped System Nd-Ce-Cu-O, Physica C, 1990, 170, p 211-214

10. B. Shinozaki, S. Takada, N. Kokubo, K. Makise, K. Mitsuichi, K. Yamada, K. Yano, and H. Nakamura, Superconducting Characteristics and Microstructure of Polycrystalline ZnDoped $\mathrm{In}_{2} \mathrm{O}_{3}$ Films, Physica $C$, 2011, 471, p 717-720

11. T. Kijima, H. Sushida, T. Noguchi, M. Yada, and M. Machida, Synthesis and Characterisation of a New Layered Cuprate $\mathrm{In}_{2} \mathrm{Ba}_{2} \mathrm{CuO}_{6-\delta}$, J. Solid State Chem., 1997, 131, p 177-180

12. R. Horyń, E. Bukowska, and A. Sikora, Studies of $\mathrm{BaO}-\mathrm{In}_{2} \mathrm{O}_{3}$ $\mathrm{CuO}$ Ternary System. Part I: Phase Equilibria in the Isothermal Cross-Section of $930^{\circ} \mathrm{C}$, J. Alloy. Compd., 2000, 305, p 103-108

13. O.V. Godzhieva, N.V. Porotnikov, and V.P. Pikhidchuk, Physical-Chemical Study of Triple Oxides Formed in $\mathrm{In}_{2} \mathrm{O}_{3}$ CaO-CuO System, Zhur. Neorg. Khim., 1992, 37, p 1184-1188

14. M. Marezio, Refinement of Crystal Structure of $\mathrm{In}_{2} \mathrm{O}_{3}$ at 2 Wavelengths, Acta Crystallogr., 1996, 20, p 723-728 
15. J.K. Liang, C. Zhan, W. Fei, and S.S. Xie, Phase-Diagram of SrO-CaO-CuO Ternary-System, Solid State Commun., 1990, 75, p 247-252

16. A.S. Kosmynin, B.V. Slobodin, V.L. Balashov, I.K. Garkushin, A.A. Fotiev, and A.S. Trunin, Phase-Equilibria in the CaO-SrO$\mathrm{CuO}$ System ( $\geq 70 \mathrm{~mol} \% \mathrm{CuO})$, Inorg. Mater., 1995, 7, p 867-870

17. N.M. Hwang, R.S. Roth, and C.J. Rawn, Phase-Equilibria in the Systems $\mathrm{SrO}-\mathrm{CuO}$ and $\mathrm{SrO}-1 / 2 \mathrm{Bi}_{2} \mathrm{O}_{3}, J$. Am. Ceram. Soc., 1990, 73, p 2531-2533

18. R.O. Suzuki, P. Bohac, and L.J. Gauckler, Thermodynamics and Phase-Equilibria in the $\mathrm{Sr}-\mathrm{Cu}-\mathrm{O}$ System, J. Am. Ceram. Soc., 1992, 75, p 2833-2842

19. M. Nevriva and H. Kraus, Study of Phase-Equilibria in the Partially Open Sr-Cu-(O) System, Physica C, 1994, 235-240, p 325-326

20. C.B. Alcock and B.Z. Li, Thermodynamic Study of the Cu-SrO System, J. Am. Ceram. Soc., 1990, 73, p 1176-1180

21. M.T. Weller and D.R. Lines, Structure and Oxidation-State Relationships in Ternary Copper Oxides, J. Solid State Chem., 1989, 82, p 21-29

22. E.M. McCarron, M.A. Subramanian, J.C. Calabrese, and R.L. Harlow, The Incommensurate Structure of $\left(\mathrm{Sr}_{14-x} \mathrm{Ca}_{x}\right) \mathrm{Cu}_{24} \mathrm{O}_{41}$ $(0<x \sim 8)$ a Superconductor By-Product, Mater. Res. Bull., 1988, 23, p 1355-1365

23. C.L. Teske and H. Müller-Buschbaum, Über ErdalkalimetallOxocuprate. Alkaline Earth Metal Oxocuprates. 4. $\mathrm{SrCu}_{2} \mathrm{O}_{2}$, Z. Anorg. Allg. Chem., 1970, 379, p 113-121

24. N. Kobayashi, Z. Hiroi, and M. Takano, Compounds and Phase Relations in the SrO-CaO-CuO System Under High Pressure, J. Solid State Chem., 1997, 132, p 274-283

25. H.-R. Freund and H. Müller-Buschbaum, Oxocuprates. 25. About $\mathrm{In}_{2} \mathrm{Cu}_{2} \mathrm{O}_{5}$, Z. Anorg. Allg. Chem., 1978, 441, p 103-106

26. E.L. Belokoneva, L.I. Leonyuk, and N.I. Leonyuk, Single Crystal Growth and Crystal Structures of $\mathrm{In}_{2} \mathrm{CuO}_{4}(\mathrm{Nd}, \mathrm{Ce})_{2-}$ $\mathrm{CuO}_{4}$ and of the Tetragonal Copper Deficient $\mathrm{Sm}(\mathrm{Ba}, \mathrm{Sm})_{2-}$ $\mathrm{Cu}_{3-y} \mathrm{O}_{z}$ Phase, Svekhprovodimost, 1991, 4, p 563-569

27. Z. Li, J. Sun, L. You, H. Jiao, G. Li, X. Jing, F. Liao, and J. Lin, Phase Equilibrium of the $\mathrm{In}_{2} \mathrm{O}_{3}-\mathrm{TiO}_{2}-\mathrm{MO}(\mathrm{M}=\mathrm{Ca}, \mathrm{Sr})$ Systems and the Structure of $\mathrm{In}_{6} \mathrm{Ti}_{6} \mathrm{CaO}_{22}$, Chem. Mater., 2005, 17, p 2186-2192
28. R. von Schenk and H. Müller-Buschbaum, Alkaline-Earth Oxoindates. 3. Crystal-Structure Investigation on $\mathrm{SrIn}_{2} \mathrm{O}_{4}, Z$. Anorg. Allg. Chem., 1973, 398, p 24-30

29. R. von Schenk and H. Müller-Buschbaum, New AlkalineEarth Metal Oxoindate- $\mathrm{Sr}_{2} \mathrm{In}_{2} \mathrm{O}_{5}$, Z. Anorg. Allg. Chem., 1973, 395, p 280-286

30. T.J.B. Holland and S.A.T. Redfern, Unit Cell Refinement from Powder Diffraction Data: The Use of Regression Diagnostics, Mineral. Mag., 1997, 61, p 65-77

31. X. Li, C. Xia, X. He, X. Gao, S. Liang, G. Pei, and Y. Dong, Enhancement of Ferromagnetic Properties in $\mathrm{In}_{1.99} \mathrm{Co}_{0.01} \mathrm{O}_{3}$ by Additional Cu Doping, Scripta Mater., 2008, 58, p 171-174

32. M. Sasaki, K. Yasui, S. Kohiki, H. Deguchi, S. Matsushima, M. Oku, and T. Shishido, $\mathrm{Cu}$ Doping Effect on Optical and Magnetic Properties of $\mathrm{In}_{2} \mathrm{O}_{3}$, J. Alloy. Compd., 2002, 334, p 205-210

33. J.-C. Grivel and N.H. Andersen, Subsolidus Phase Relations of the SrO- $\mathrm{RE}_{2} \mathrm{O}_{3}-\mathrm{CuO}$ Systems $(\mathrm{RE}=\mathrm{Tm}, \mathrm{Lu}$ and $\mathrm{Sc})$, J. Alloy. Compd., 2005, 391, p 292-295

34. F. Wu, S. Xie, Z. Chen, and J. Ling, Subsolidus Phase Relations of the $\mathrm{Y}_{2} \mathrm{O}_{3}$-SrO-CuO System, J. Mater. Sci., 1992, 27, p 3082-3084

35. W. Wong-Ng, Q. Huang, I. Levin, J.A. Kaduk, J. Dillingham, T. Haugan, J. Suh, and L.P. Cook, Crystal Chemistry and Phase Equilibria of Selected $\mathrm{SrO}-\mathrm{R}_{2} \mathrm{O}_{3}-\mathrm{CuO}_{x}$ and Related Systems; $\mathrm{R}=$ Lanthanides and Yttrium, Int. J. Inorg. Mater., 2001, 3, p 1283-1290

36. C.Q. Han, X.L. Chen, J.K. Liang, Q.L. Liu, Y. Chen, and G.H. Rao, The Ternary System $\mathrm{Tm}_{2} \mathrm{O}_{3}$-SrO-CuO: Compounds and Phase Relations, J. Alloy. Compd., 2000, 309, p 95-99

37. J.-C. Grivel and N.H. Andersen, Subsolidus Phase Relations of the $\mathrm{SrO}-\mathrm{Er}_{2} \mathrm{O}_{3}-\mathrm{CuO}$ System, J. Alloy. Compd., 2005, 389, p 186-189

38. J.-C. Grivel and N.H. Andersen, Subsolidus Phase Relations of the SrO- $\mathrm{REO}_{x}-\mathrm{CuO}$ Systems $(\mathrm{RE}=\mathrm{Ce}, \mathrm{Pr}$ and $\mathrm{Tb})$, J. Alloy. Compd., 2007, 436, p 261-265

39. R.D. Shannon, Revised Effective Ionic-Radii and Systematic Studies of Interatomic Distances in Halides and Chalcogenides, Acta Crystallogr. A, 1976, 32, p 751-767 